\title{
SISTEM PAKAR BERBASIS WEB UNTUK PENGENALAN DINI TERHADAP KARAKTER INVESTASI INDIVIDU
}

\author{
Albert V. Dian Sano \\ Information Systems Department, School of Information Systems, Binus University \\ Jln. K.H. Syahdan No. 9, Palmerah, Jakarta Barat 11480 \\ albert_vds@yahoo.com
}

\begin{abstract}
The objective of this research is to develop a web-based expert system for early detection towards characters of investment of people who will invest immediately on their productive ages. The development of this application is encompassing four primary activities in developing an expert system, namely: knowledge acquisition, knowledge representation, knowledge inferencing, and knowledge transfering. Knowledge acquisition is a process of acquisition or transfering knowledge or expertise of an expert through a knowledge engineer. Knowledge representation is a process of transfering knowledge into a computer based system. Knowledge inferencing is a reasoning process performed by an expert system to draw a conclusion or a final result. The reasoning process applies a forward-chaining method. Knowledge transfering is a process of transfering knowledge from an expert system to a user (non-expert one) through a user interface of the expert system. This expert system has been tested to about 300 users. This simple system generally runs quite well although there are still some weakness to refine in the further research.
\end{abstract}

Keywords: expert system, web-based applications, detection towards characters of investment

\begin{abstract}
ABSTRAK
Penelitian bertujuan untuk mengembangkan sistem pakar berbasis web untuk pengenalan dini terhadap karakter investasi seseorang yang akan berinvestasi ketika usia produktif. Pengembangan aplikasi ini meliputi empat aktivitas utama dalam mengembangkan sistem pakar, yaitu: knowledge acquisition, knowledge representation, knowledge inferencing, dan knowledge transfering. Knowledge acquisition adalah proses pengambilan atau pemindahan pengetahuan atau keahlian yang dimiliki seorang pakar oleh knowledge engineer. Knowledge representation adalah proses pemindahan pengetahuan ke dalam sistem berbasis komputer. Knowledge inferencing adalah proses penalaran yang dilakukan oleh sistem pakar untuk menarik suatu kesimpulan atau hasil akhir. Proses penalaran ini menggunakan penalaran maju (forward chaining). Knowledge transfering adalah proses pemidahan pengetahuan dari sistem pakar ke pengguna (non-expert) melalui user interface dari sistem pakar. Sistem pakar ini sudah diujicobakan kepada sekitar 300 pengguna. Meskipun sistem ini cukup sederhana dan memeliki beberapa kelemahan untuk disempurnakan pada penelitian lebih lanjut, secara umum sistem ini berjalan cukup baik.
\end{abstract}

Kata kunci: sistem pakar, aplikasi berbasis web, pengenalan karakter investasi 


\section{PENDAHULUAN}

Pada dasarnya manusia pada usia produktif perlu mengelola keuangan pribadinya. Dengan pengelolaan keuangan pribadi yang baik akan membawa kesejahteraan dan kenyamanan hidup. Salah satu aktivitas dalam pengelolaan keuangan adalah dengan merencanakan investasi. Banyak tujuan yang ingin dicapai orang dalam berinvestasi. Namun demikian inti dari semua tujuan investasi adalah sama, yaitu untuk menyiapkan kesejahteraan dan kenyamanan di masa mendatang, entah masa mendatang dalam jangka pendek maupun jangka panjang atau masa pensiun. Pilihan instrumen investasi banyak ragamnya antara lain, saham, emas, obligasi, valas, properti, dan sebagainya. Sayangnya banyak orang yang tidak menyadari pentingnya perencanaan yang baik dalam beinvestasi. Tidak adanya perencanaan yang baik dalam berinvestasi bisa menyebabkan kegagalan atau tidak tercapainya tujuan investasi. Sebagai contoh, beberapa orang berinvestasi hanya karena sekedar ikutikutan sehingga tidak tahu apakah investasinya membawa imbal hasil yang baik atau tidak. Beberapa yang lain mencoba berinvestasi namun merasa tidak cocok dengan jenis atau produk investasi yang dimilikinya sehingga hasil investasinya tidak sesuai dengan yang diharapkan.

Dalam berinvestasi, ada perspektif yang disebut sebagai behavioral finance, yaitu mood investor yang mempengaruhi perilaku transaksi mereka (Atmaja 2009:8). Jadi pada dasarnya karakter investor akan mempengaruhi seseorang dalam menjalankan transaksi investasinya atau pengelolaan portfolionya.

Semua jenis investasi, selain mengandung return atau imbal balik juga selalu mengandung risiko. Keown (2010:455) menyatakan tegas salah satu prinsip dalam kedua aspek tersebut bahwa, risiko dan return, selalu berjalan beriringan (Keown, 2010:455). High risk high return adalah jargon dalam dunia investasi yang menjadi semacam hukum dasar bagi para pelaku investasi. Karena itu, dalam berinvestasi, calon investor sebaiknya melengkapi diri dengan pengetahuan dasar investasi. Selain itu, calon investor juga sebaiknya mengetahui karakter dasar dirinya terhadap investasi. Dengan mengenali karakter investasi dirinya sendiri, calon investor bisa membuat rencana investasi yang lebih cocok bagi dirinya.

Penelitian ini bertujuan membuat rancangan sistem pakar berbasis web untuk pengenalan dini karakter investasi individu calon investor. Sistem pakar dapat didefinisikan sebagai program komputer yang dimaksudkan untuk memodelkan pengetahuan dan keahlian seorang pakar (melakukan penyelesaian masalah) dalam domain tertentu. Jadi tujuan dari sistem pakar adalah memindahkan pengetahuan yang dimiliki oleh seorang pakar ke dalam komputer. Kemudian komputer yang meneruskan pengetahuan ini ke orang lain yang bertindak sebagai pengguna (non-expert). Sedangkan aplikasi berbasis web bertujuan supaya aplikasi tersebut bisa digunakan oleh pengguna tanpa batasan lokasi sehingga bisa diakses dimanapun selama ada koneksi internet, tanpa batasan waktu sehingga bisa diakses kapanpun, dan lebih murah karena tidak memerlukan software khusus melainkan hanya memerlukan browser untuk mengakses aplikasi tersebut.

\section{METODE}

Metode penelitian ini berfokus pada menjalankan aktivitas-aktivitas utama yang ada dalam merancang sistem pakar. Menurut Tolle (2008: 2), aktivitas-aktivitas tersebut adalah: (1) knowledge acquisition, yaitu proses untuk mendapatkan pengetahuan yang dimiliki oleh seorang pakar; (2) knowledge representation, yaitu proses untuk memindahkan pengetahuan ke dalam computer; (3) knowledge inferencing, yaitu proses penalaran yang dilakukan komputer untuk mengambil suatu 
kesimpulan; (4) knowledge transfering, yaitu proses memindahkan pengetahuan yang berupa kesimpulan ke individu (non-expert) yang bertindak sebagai pengguna.

\section{Knowledge Acquisition}

Tahap ini adalah proses mendapatkan pengetahuan dari seorang pakar, dalam hal ini adalah pakar dalam bidang investasi dan perencana keuangan. Proses ini dilakukan dengan teknik interview dan diskusi antara knowledge engineer atau dalam hal ini peneliti dan pakar tersebut mengenai pengkategorian karakter calon investor dalam pengelolaan keuangan pribadi secara umum. Setelah mengadakan serangkaian diskusi dan interview bisa ditarik kesimpulan bahwa pada dasarnya karakter calon investor terdiri dari lima kategori karakter dasar, yaitu: (1) konservatif - mereka yang berkeinginan untuk mempertahankan modal dan penghasilan saat ini. Pertumbuhan investasi bukan merupakan tujuan mereka. Maka dari itu, mereka cenderung untuk menghindari risiko investasi dan memilih instrumen investasi jangka pendek; (2) seimbang. - mereka yang berkeinginan untuk segera mendapatkan penghasilan saat ini. Pertumbuhan investasi sudah merupakan tujuan. Mereka cenderung menghindari risiko investasi dan memilih instrumen investasi jangka pendek atau menengah; (3) moderat - mereka yang berkeinginan untuk mendapatkan penghasilan saat ini dan bertujuan untuk pertumbuhan investasi. Mereka cukup toleransi terhadap risiko investasi dan memilih instrumen investasi jangka menengah; (3) bertumbuh - mereka yang kurang berkeinginan untuk mendapatkan penghasilan saat ini. Tujuan mereka berfokus pada pertumbuhan investasi. Mereka juga memiliki toleransi yang tinggi terhadap risiko investasi dan memilih instrumen investasi jangka menengah atau panjang; (4) Agresif - mereka tidak berkeinginan untuk mendapatkan penghasilan saat ini dan bertujuan pada pertumbuhan investasi yang pesat. Sehingga mereka memiliki toleransi yang tinggi terhadap risiko investasi dan memilih instrumen investasi jangka panjang.

\section{Knowledge Representation}

Sebagai sarana untuk penyajian pengetahuan atau knowledge representasion digunakan perancangan basis pengetahuan yang menggunakan kaidah produksi. Kaidah produksi disini akan ditulis dalam bentuk pernyataan IF sebagai premis, THEN sebagai konklusi. Pada perancangan basis pengetahuan sistem pakar ini premis adalah berupa serangkaian jawaban atas pertanyaan-pertanyaan yang ditanyakan oleh sistem dan konklusi adalah skor atas jawaban yang diinputkan oleh pengguna.

Berikutnya adalah penyusunan konsultasi antara sistem pakar dengan pengguna. Proses ini memerlukan beberapa teknik bantu dengan rangkain pertanyaan yang nantinya harus dijawab oleh pengguna. Rangkaian pertanyaan ini disimpan ke dalam komputer. Pertanyaan-pertanyaan yang diajukan berupa pilihan jawaban menggunakan radio button. Teknik alat bantu berikutnya adalah pemberian skor terhadap setiap jawaban yang diberikan. Jumlah pertanyaan yang diajukan sebanyak 16 pertanyaan. Pertanyaan-pertanyaan tersebut dibagi menjadi tiga kategori, yaitu mengenai: (1) informasi umum calon investor yang akan didiagnosa; (2) tujuan investasi sang calon investor; (3) toleransi risiko terhadap investasi dari sang calon investor. Teknik alat bantu ketiga adalah pemberian bobot terhadap masing-masing kategori tersebut. Tabel 1 menunjukkan kategori karakter investasi dan deskripsi atas karakter tersebut.

Tabel 1

Karakter Investasi Pengguna

\begin{tabular}{lll}
\hline Skor & Hasil & Deskripsi \\
\hline 35-59 & Konservatif & $\begin{array}{l}\text { Berkeinginan untuk mempertahankan modal dan penghasilan saat ini, pertumbuhan } \\
\text { investasi bukan merupakan tujuan, cenderung untuk menghindari risiko investasi dan } \\
\text { memilih instrumen investasi jangka pendek }\end{array}$ \\
\hline $60-86$ & Seimbang & $\begin{array}{l}\text { Berkeinginan untuk segera mendapatkan penghasilan saat ini, pertumbuhan investasi } \\
\text { sudah merupakan tujuan, cenderung untuk menghindari risiko investasi dan memilih }\end{array}$ \\
\hline
\end{tabular}




\begin{tabular}{lll}
\hline 87-103 & Moderat & $\begin{array}{l}\text { instrumen investasi jangka pendek / menengah } \\
\text { Berkeinginan untuk mendapatkan penghasilan saat ini, bertujuan untuk pertumbuhan } \\
\text { investasi, cukup toleransi terhadap risiko investasi dan memilih instrumen investasi } \\
\text { jangka menengah }\end{array}$ \\
\hline 104-119 & Bertumbuh & $\begin{array}{l}\text { Kurang berkeinginan untuk mendapatkan penghasilan saat ini, bertujuan pada } \\
\text { pertumbuhan investasi, toleransi yang tinggi terhadap risiko investasi dan memilih } \\
\text { instrumen investasi jangka menengah / panjang }\end{array}$ \\
\hline$>=120$ & Agresif & $\begin{array}{l}\text { Tidak berkeinginan untuk mendapatkan penghasilan saat ini, bertujuan pada } \\
\text { pertumbuhan investasi yang pesat, toleransi yang tinggi terhadap risiko investasi dan } \\
\text { memilih instrumen investasi jangka panjang }\end{array}$ \\
\hline
\end{tabular}

Pada sistem pakar untuk pengenalan dini terhadap karakter investasi individu ini, diajukan 16 pertanyaan yang terbagi menjadi tiga kategori. Daftar 16 pertanyaan tersebut adalah sebagai berikut:

I. Informasi umum berinvestasi

1. Berapakah usia Bapak/Ibu?
a. 56 tahun keatas
b. $46-55$ tahun
c. $35-45$ tahun
d. 20-34 tahun

2. Apakah sasaran investasi Bapak/Ibu yang utama?
a. Pemeliharaan kekayaan
b. Rencana setelah pensiun
c. Pengumpulan kekayaan

3. Berapakah batasan waktu bagi Bapak/Ibu untuk mencapai sasaran investasi Bapak/Ibu?
a. $0-2$ tahun
b. 2-5 tahun
c. 5-10 tahun
d. 10 tahun atau lebih

4. Bagaimana susunan portfolio Bapak/Ibu saat ini?
a. Produk bank (seperti giro, tabungan, deposito berjangka, dan sebagainya) $100 \%$
b. Produk bank $75 \%$, produk investasi $25 \%$
c. Produk bank $50 \%$, produk investasi $50 \%$
d. Produk bank $25 \%$, produk investasi $75 \%$

II. Tujuan investasi

5. Manakah dari pernyataan berikut yang menggambarkan tujuan investasi Bapak/Ibu?

a. Mempertahankan uang pokok dan mendapatkan jumlah yang cukup dari penghasilan saat ini

b. Menghasilkan jumlah yang tinggi dari penghasilan saat ini

c. Menghasilkan penghasilan saat ini dan pertumbuhan aktiva diperpanjang melebihi batasan waktu

d. Menumbukan aktiva secara substansial diperpanjang melebihi batasan waktu.

6. Bagaimana Bapak/Ibu mengekspektasi standar hidup lima tahun dari sekarang dibandingkan dengan standar hidup saat ini?
a. Tak sebanyak dengan saat ini
b. Sama dengan saat ini
c. Sedikit lebih tinggi dari saat ini
d. Secara substansial lebih besar dari saat ini

7. Lima tahun dari saat ini, Bapak/Ibu mengharapkan nilai portfolio seperti:
a. Nilai portfolio bukanlah perhatian utama saya karena saya lebih memperhatikan penghasilan saya saat ini
b. Sama dengan atau sedikit lebih besar dari saat ini
c. Lebih besar dari saat ini
d. Secara substansial lebih besar dari saat ini

8. Menghasilkan penghasilan saat ini melalui portfolio Bapak/Ibu adalah: 
a. Perhatian yang utama (hanya jika Bapak/Ibu akan pensiun)

b. Tidak penting

9. Dengan penghasilan yang dihasilkan melalui portfolio yang akan datang, Bapak/Ibu merencanakan untuk:

a. Mempergunakannya untuk kebutuhan hidup

b. Mempergunakannya sebagian dan menginvestasikan kembali sebagian

c. Menginvestasikan kembali semua penghasilan

III. Toleransi risiko

10. Bapak/Ibu baru saja menerima rejeki yang tak disangka-sangka uang sebesar 500 juta rupiah. Bagaimana Bapak/Ibu akan menginvestasikannya?

a. Saya akan menginvestasikan pada sesuatu yang ditawarkan yang cukup dari penghasilan saat ini dan konservatif

b. Saya akan menginvestasikan pada sesuatu yang ditawarkan yang tinggi dari penghasilan saat ini dengan resiko yang cukup

c. Saya akan menginvestasikan pada sesuatu yang ditawarkan tinggi tingkat total pengembalian (penghasilan saat ini ditambah apresiasi modal) dengan resiko cukup tinggi

d. Saya akan menginvestasikan pada sesuatu yang secara substansial apresiasi modal sekalipun terdapat resiko yang tinggi

11. Manakah dari penyataan berikut yang mengggambarkan reaksi Bapak/Ibu jika nilai dari portfolio Bapak/Ibu tiba-tiba turun 15\%?

a. Saya akan sangat memperhatikan karena saya tidak dapat menerima fluktuasi nilai portfolio saya

b. JIka tidak mempengaruhi juimlah penghasilan yang saya terima, hal tersebut tidaklah mempengaruhi saya

c. Meskipun saya menginvestasikan untuk pertumbuhan jangka panjang, saya akan memperhatikan seperti halnya penurunan sementara

d. Karena saya menginvestasikan untuk pertumbuhan jangka panjang, saya menerima fluktuasi sementara sesuai pengaruh pasar

12. Manakah dari investasi berikut yang Bapak/Ibu rasa paling nyaman untuk dimiliki?

a. Sertifikat deposito

b. Obligasi Pemerintah

c. Saham yang baik

d. Saham perusahaan yang baru dan yang berkembang

13. Manakah dari investasi berikut yang Bapak/Ibu rasa kurang ingin Bapak/Ibu miliki?

a. Saham perusahaan yang baru dan yang berkembang

b. Saham yang baik

c. Obligasi Pemerintah

d. Sertifikat deposito

14. Manakah dari investasi berikut menurut Bapak/ibu rasa yang paling ideal untuk portfolio Bapak/Ibu?

a. Sertifikat deposito

b. Obligasi Pemerintah

c. Saham yang baik

d. Saham perusahaan yang baru dan yang berkembang

15. Seberapa optimis Bapak/Ibu tentang prospek jangka panjang terhadap perekonomian?

a. Sangat pesimistis

b. Tidak yakin

c. Agak optimis

d. Sangat optimis

16. Manakah dari berikut yang menggambarkan sikap Bapak/Ibu mengenai dunia investasi?

a. Tidak yakin

b. Saya percaya bahwa ekonomi dalam negeri dan pasar luar negeri itu saling bergantung

c. Saya percaya bahwa pasar luar negeri menyediakan kesempatan investasi yang menarik 
Ilustrasi user interface konsultasi antara sistem pakar dengan pengguna adalah seperti terlihat dalam Gambar 1 di bawah ini:

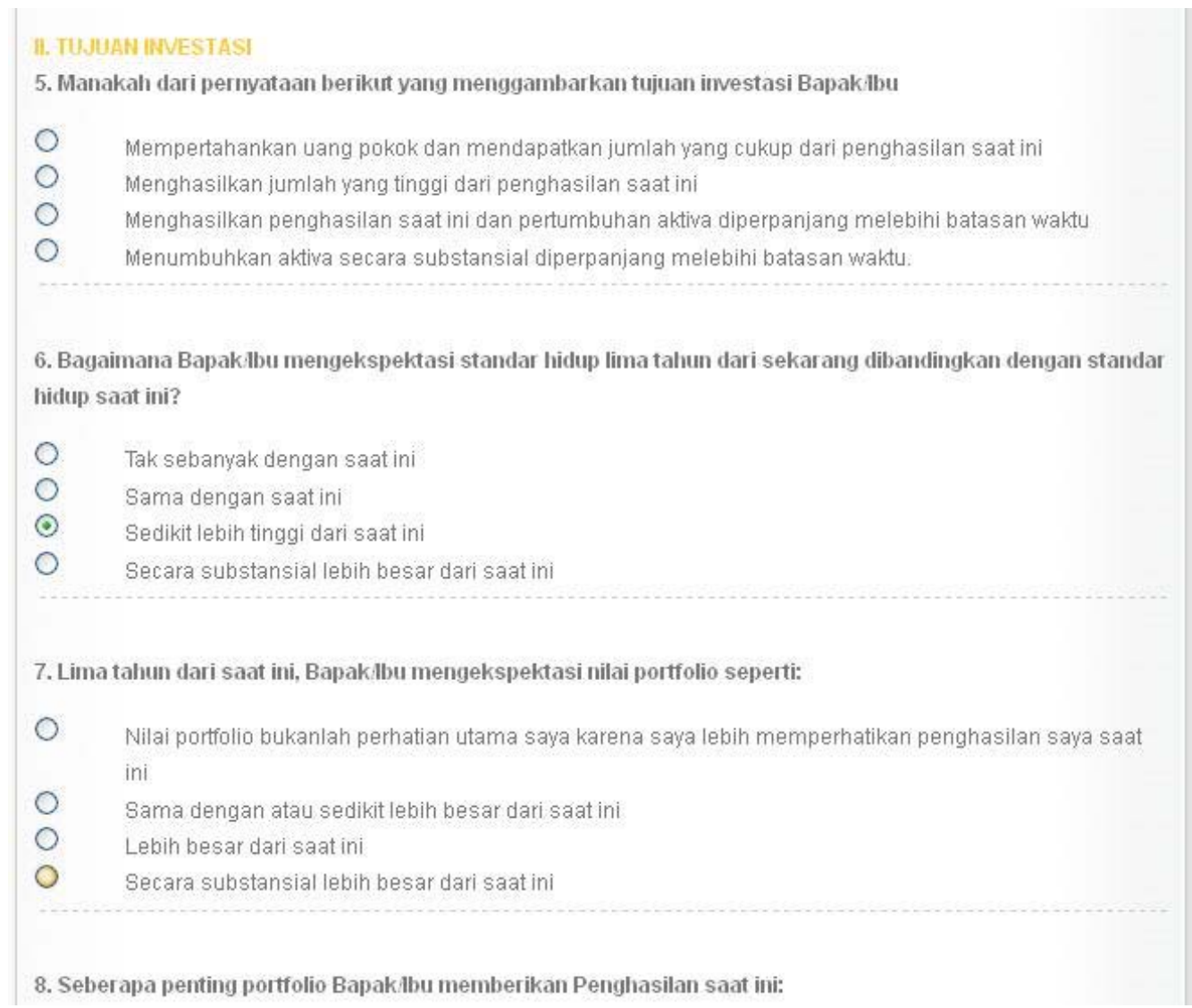

Gambar 1. Screenshot user interface untuk konsultasi dengan sistem pakar.

\section{Knowledge Inferencing}

Tahap ini adalah proses penalaran yang dilakukan oleh sistem pakar. Metode yang digunakan dalam penalaran ini adalah forward chaining atau proses penalaran maju. Proses penalaran dimulai dari sekumpulan fakta yang berupa kumpulan jawaban tentang suatu indikasi karakter yang diberikan pengguna sebagai input dalam sistem pakar ini. Kemudian proses penalaran akan berlanjut sampai dengan akhir proses diagnosa kemungkinan jenis karakter individu pengguna atau sang calon investor.

Proses penalaran oleh sistem dimulai dengan pemberian skor terhadap masing-masing pertanyaan. Pemberian skor untuk pertanyaan bisa dilihat dalam Tabel 2 berikut:

Tabel 2

Skor Masing-masing Jawaban Pertanyaan

\begin{tabular}{ccc}
\hline Pertanyaan & Jawaban & Skor \\
\hline 1 & A & 1 \\
& B & 2 \\
& C & 3 \\
& D & 4 \\
\hline 2 & A & 1 \\
& B & 2 \\
\hline
\end{tabular}




\begin{tabular}{|c|c|c|}
\hline & $\mathrm{C}$ & 3 \\
\hline \multirow[t]{4}{*}{3} & $\mathrm{~A}$ & 1 \\
\hline & B & 2 \\
\hline & $\mathrm{C}$ & 3 \\
\hline & D & 4 \\
\hline \multirow[t]{4}{*}{4} & $A$ & 1 \\
\hline & B & 2 \\
\hline & $\mathrm{C}$ & 3 \\
\hline & $\mathrm{D}$ & 4 \\
\hline \multirow[t]{4}{*}{5} & A & 1 \\
\hline & B & 2 \\
\hline & $\mathrm{C}$ & 3 \\
\hline & $\mathrm{D}$ & 4 \\
\hline \multirow[t]{4}{*}{6} & $\mathrm{~A}$ & 1 \\
\hline & B & 2 \\
\hline & $\mathrm{C}$ & 3 \\
\hline & $\mathrm{D}$ & 4 \\
\hline \multirow[t]{4}{*}{7} & A & 1 \\
\hline & B & 2 \\
\hline & $\mathrm{C}$ & 3 \\
\hline & $\mathrm{D}$ & 4 \\
\hline \multirow[t]{2}{*}{8} & $A$ & 1 \\
\hline & B & 2 \\
\hline \multirow[t]{4}{*}{9} & A & 1 \\
\hline & B & 2 \\
\hline & $\mathrm{C}$ & 3 \\
\hline & & 4 \\
\hline \multirow[t]{4}{*}{10} & $\mathrm{~A}$ & 1 \\
\hline & B & 2 \\
\hline & $\mathrm{C}$ & 3 \\
\hline & $\mathrm{D}$ & 4 \\
\hline \multirow[t]{4}{*}{11} & A & 1 \\
\hline & B & 2 \\
\hline & $\mathrm{C}$ & 3 \\
\hline & $\mathrm{D}$ & 4 \\
\hline \multirow[t]{4}{*}{12} & $\mathrm{~A}$ & 1 \\
\hline & B & 2 \\
\hline & $\mathrm{C}$ & 3 \\
\hline & $\mathrm{D}$ & 4 \\
\hline \multirow[t]{4}{*}{13} & A & 1 \\
\hline & B & 2 \\
\hline & $\mathrm{C}$ & 3 \\
\hline & $\mathrm{D}$ & 4 \\
\hline \multirow[t]{4}{*}{14} & $\mathrm{~A}$ & 1 \\
\hline & B & 2 \\
\hline & $\mathrm{C}$ & 3 \\
\hline & $\mathrm{D}$ & 4 \\
\hline \multirow[t]{4}{*}{15} & $A$ & 1 \\
\hline & B & 2 \\
\hline & $\mathrm{C}$ & 3 \\
\hline & D & 4 \\
\hline \multirow[t]{3}{*}{16} & $\mathrm{~A}$ & 1 \\
\hline & B & 2 \\
\hline & $\mathrm{C}$ & 3 \\
\hline
\end{tabular}


Proses penalaran berikutnya oleh sistem adalah dengan pemberian bobot terhadap masingmasing kategori pertanyaan. Seperti telah dibahas di atas bahwa 16 pertanyaan tersebut terbagi ke dalam tiga kategori pertanyaan diagnosa, yaitu tentang: (1) informasi umum investasi; (2) tujuan investasi; (3) toleransi risiko investasi. Kategori pertama adalah pertanyaan-pertanyaan pada nomor satu sampai dengan empat. Kategori kedua adalah pertanyaan-pertanyaan pada nomor 5 sampai dengan 9. Sedangkan kategori ketiga adalah pertanyaan-pertanyaan pada nomor 10 sampai dengan 16. Bobot pada kategori pertama adalah satu. Bobot pada kategori kedua adalah 2. Dan bobot pada kategori ketiga adalah 3 .

Hasil akhir untuk diagnosa terhadap pengenalan dini karakter investasi individu dihitung berdasarkan hasil penjumlahan total semua kategori. Sedangkan total masing-masing kategori adalah total skor dikalikan dengan bobot kategorinya. Secara matematis bisa dirumuskan sebagai berikut:

\$_kategori_1 $=$ \$_hasil_penjumlahan_skor $* 1$

\$_kategori_2 = \$_hasil_penjumlahan_skor $* 2$

\$_kategori_3 = \$_hasil_penjumlahan_skor * 3

\$_hasil akhir $=$ \$_kategori_1 + \$_kategori_2 + \$_kategori_3

Setelah sistem melakukan proses penghitungan, kemudian diberikan kesimpulan yang ditujukan ke pengguna.

\section{Knowledge Transfering}

Tahap ini adalah proses pemindahan pengetahuan dari sistem pakar ke pengguna. Proses pemidahan dilakukan oleh sistem pakar melalui user interface. Fungsi user interface dalam sistem pakar ini selain sebagai sarana untuk memindahkan pengetahuan dari sistem ke pengguna juga sebagai sarana konsultasi melalui komunikasi tanya jawab antara pengguna dengan sistem. Screenshot ilustrasi user interface hasil konsultasi antara pengguna dan sistem pakar seperti terlihat pada Gambar 2.

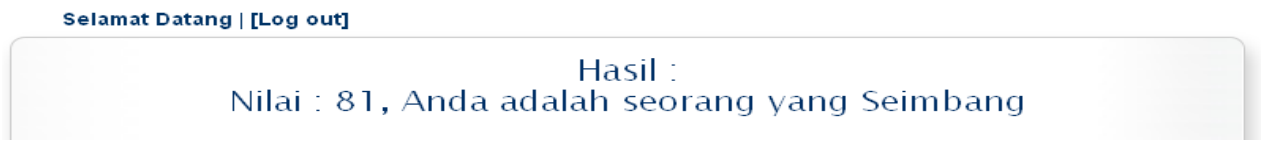

Gambar 2. Screenshot ilustrasi hasil konsultasi antara pengguna dengan sistem pakar.

\section{HASIL DAN PEMBAHASAN}

Aplikasi sistem pakar ini menggunakan metode inferensi berbasis forward-chaining. Metode inferensi forward-chaining lebih tepat dan lebih alami diterapkan untuk menyelesaikan permasalahanpermasalahan yang memiliki berbagai kemungkinan hipotesis. Sedangkan metode berbasis backwardchaining lebih tepat dan lebih alami duterapkan untuk menyelesaikan permasalahan-permasalahan dengan hipothesa yang telah ditentukan sebelumnya. Karena itu, dalam aplikasi ini dipilih untuk menerapkan metode inferensi berbasis forward-chaining.

Langkah-langkah dalam penerapan algorithma forward-chaining bisa dideskripsikan sebagai berikut: (1) catat fakta yang di-input user; (2) cek rule pertama; (3) bila premis sesuai dengan working memory, simpan kesimpulan sementara ke memory dan iterasi kembali ke nomor 2 dengan rule berikutnya; (4) bila premis tidak sesuai, cek apakah masih ada rule lagi; (5) bila ada rule lagi, cek ke 
rule selanjutnya (langkah nomor 2); (6) bila tidak ada rule lagi, program selesai. Untuk lebih jelasnya, algoritma di atas bisa diilustrasikan seperti dalam Gambar 3 berikut:

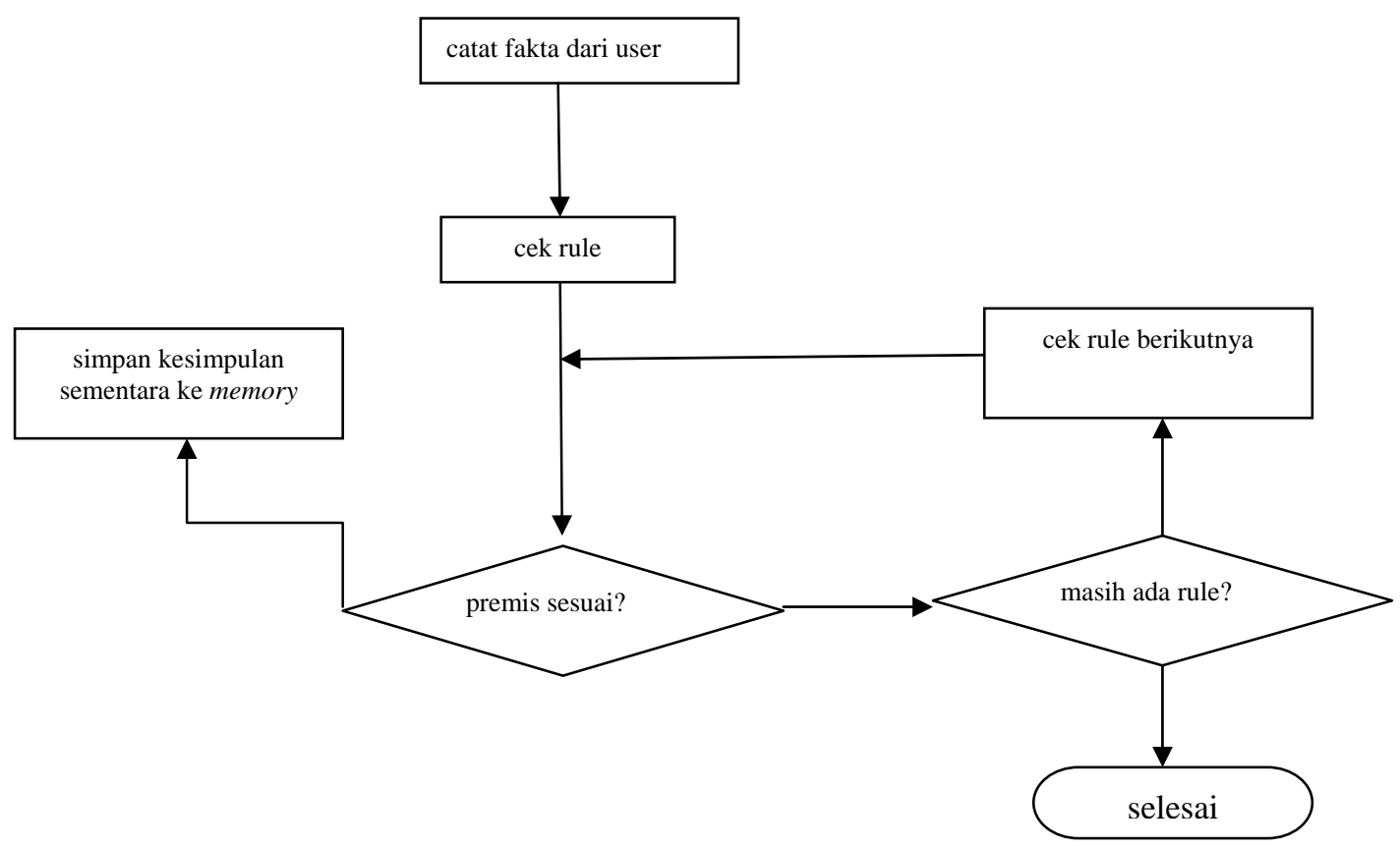

Gambar 3. Ilustrasi algorithma forward-chaining.

Aplikasi sistem pakar untuk pengenalan dini terhadap karakter investasi ini sudah diujicobakan kepada sekitar 300 pengguna. Hasilnya cukup baik dan cukup membantu pengguna dalam mengenali secara dini karakter investasi individu mereka. Dengan begitu, hasil konsultasi dengan sistem pakar ini diharapkan mampu memotivasi para pengguna untuk mendalami lebih lanjut mengenai strategi yang harus diterapkan dalam menyusun perencanaan investasi mereka.

Kelebihan lain sistem pakar ini adalah aplikasi yang berbasis web. Sehingga para klien pengguna bisa melakukan diagnosa berkali-kali, kapanpun dan dimanapun.

Beberapa kelemahan dan kekurangan dalam sistem pakar ini juga dicatat supaya bisa dikaji dan dikembangkan dalam penelitian lebih lanjut sehingga bisa melengkapi kelemahan dan kekurangan yang ada dalam sistem ini. Beberapa kelemahan dan kekurangan tersebut antara lain: (1) aplikasi sistem pakar ini masih mengabaikan faktor ketidakpastian. Untuk meningkatkan fleksibilitas dan hasil yang lebih akurat dalam memberikan hasil, sistem pakar ini perlu ditambahkan teori tertentu untuk mengatasi ketidakpastian jawaban yang kadang-kadang dihadapi pengguna. Menurut Rohman dan Fauzijah (2008:8), banyak teknik yang telah ditemukan yang bisa diterapkan untuk menangani masalah ketidakpastian ini, misalnya probabilitas klasik, probabilitas bayes, teori hartley berdasarkan himpunan klasik, teori shannon berdasarkan pada probabilitas, teori Depmster-Shafer, teori fuzzy Sadeh, dan faktor kepastian atau certainty factor (Rohman dan Fauzijah, 2008: 8). Karena dalam sistem ini tidak diterapkan penghitungan untuk menghitung ketidakpastian, hal ini sama artinya dengan mengasumsikan certainty factor dengan nilai 1; (2) pemberian gradasi skor atau formulasi skor perlu dikaji lebih dalam supaya memberikan hasil yang lebih akurat, misalnya dengan menerapkan pendekatan formula matematika tertentu; (3) pemberian gradasi bobot atau formulasi bobot perlu dikaji lebih dalam supaya memberikan hasil yang lebih akurat, dengan menerapkan pendekatan formula matematika tertentu; (4) pertanyaan-pertanyaan yang diajukan oleh sistem ke pengguna perlu dievaluasi dan dikaji lebih dalam karena dunia investasi bersifat dinamis dan mengalami perubahan 
dari waktu ke waktu; (5) sistem pakar ini perlu ditambahkan fungsi rekomendasi lebih lanjut mengenai kombinasi jenis atau produk investasi apa saja yang lebih tepat bagi pengguna berdasarkan kondisi pengguna karakter investasi individu yang telah terdeteksi, misalnya investasi atau karakter investasi seperti apa yang lebih pas untuk usia pengguna saat ini, atau hasil yang ingin dicapai di masa mendatang, kemampuan keuangan saat ini, dan sebagainya. Dengan adanya fungsi rekomendasi yang lebih jauh ini, diharapkan bisa lebih memotivasi pengguna untuk segera berinvestasi secara bijak; (6) sistem pakar ini perlu ditambahkan simulasi untuk menghitung beberapa alternatif investasi. Misalnya, berapa uang yang harus disisihkan tiap bulan untuk mencapai return tertentu dalam jangka waktu lima tahun. Atau berapa perkiraan return yang akan didapat selama 30 tahun bila membeli produk investasi tertentu (misalnya reksadana syariah) dengan menyisihkan satu juta per bulan.

\section{PENUTUP}

Pada usia produktif seharusnya setiap individu menyadari pentingnya investasi. Investasi adalah salah satu instrumen penting dalam pengelolaan keuangan pribadi. Sebelum berinvestasi, calon investor sebaiknya mengenali secara dini karakter investasi pada dirinya sendiri. Pengenalan dini ini diperlukan supaya seseorang lebih nyaman dalam berinvestasi dan supaya lebih pas dalam memilih produk atau jenis investasi yang sesuai dengan dirinya. Penelitian ini bertujuan untuk mengembangkan sistem pakar berbasis web untuk pengenalan dini terhadap karakter investasi seseorang.

Aplikasi berbasis web sengaja dipilih karena sifatnya yang murah, mudah diakses kapanpun dan dimanapun. Dalam ujicoba, sistem pakar ini cukup berjalan dengan baik dalam membantu seseorang dalam mengenali karakter investasi individu mereka. Penyempurnaan terhadap sistem pakar ini juga perlu dilakukan untuk memberikan hasil yang lebih akurat, terutama untuk mengatasi hal ketidakpastian, kajian yang lebih jauh dalam pemberian skor dan bobot untuk memberikan hasil penalaran yang lebih akurat.

Penelitian untuk mengembangkan sistem pakar ini lebih jauh lagi juga diperlukan terutama dengan menambahkan rekomendasi tentang jenis atau produk investasi yang lebih cocok bagi pengguna berkaitan dengan kondisi pengguna, misalnya usia, kemampuan keuangan, target return di masa mendatang, dan sebagainya. Selain itu, perlu juga penelitian dan pengembangan lebih jauh dengan menambahkan fasilitas simulasi dalam berinvestasi.

\section{DAFTAR PUSTAKA}

Atmaja, L. S. (6 September, 2009). Aroma Ketupat Lebaran di Bursa. Harian Kontan, halaman 7.

Keown, A. J. (2010). Personal Finance: Turning Money Into Wealth. New Jersey: Pearson Education.

Rohman, F. F. \& Fauzijah, A. (2008). Rancang bangun aplikasi sistem pakar untuk menentukan jenis gangguan perkembangan pada anak. Media Informatika, 6(1). Diakses 14 Februari 2012 dari http://journal.uii.ac.id/index.php/media-informatika/article/viewFile/106/66

Tolle, H. (2008). Pengantar Sistem Pakar. Diakses 14 Februari 2012 dari http://informatikaunkris.ac.id/img/buku/sistem-pakar-5.pdf 